\title{
Dilemma of Development: Impact of Small Landholding Size on Economic Development with Special Reference to Scheduled Caste Population in Azamgarh
}

\author{
*1Neeraj Singh \& ${ }^{2}$ Azizur Rahman Siddiqui \\ 1DPhil Research Scholar, Department of Geography, University of Allahabad, Allahabad \\ 2Professor, Department of Geography, University of Allahabad, Allahabad
}

\begin{abstract}
Small-scale farming is important as it is the chief provider of livelihood to poor people, especially in a developing country like India. Thus, investments in increasing farm productions from small and intensively cultivated land are important for reducing global poverty. Based on primary survey, landholding size of Scheduled Caste population in different blocks of Azamgarh district were analysed for this study. The study shows that SC farmers still face economic deprivation in the form of small farm size that is detrimental to their social and economic growth.
\end{abstract}

Keywords: Landholding Size, Farmers, Azamgarh Scheduled Caste

\section{Article Publication}

Published Online: 15-Dec-2021

*Author's Correspondence

8 Neeraj Singh

8 DPhil Research Scholar, Department of Geography, University of Allahabad, Allahabad

$\square$ neerajsingh.geo[at]gmail.com

C 2021The Authors. Published by RESEARCH REVIEW International Journal of Multidisciplinary.This is an open access article under the CC BY-

NC-ND license

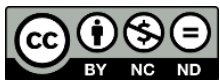

(https://creativecommons.org/licenses/ by-nc-nd/4.0/)

\section{Introduction}

The landholding size has an enormous impact on the social and economic life of farmers. Previous researches have shown that farmers with large landholdings have more disposable income and are thus, able to offer better education and health to their families. Small farmers meanwhile are hard put to feed their families and are not able to offer higher education or advanced medical facilities. Children from such families drop out from schools early and help their parents in earning money. As such, even after growing up, they have work as daily wage labourers or in their parents' small agricultural field.

The current study explores the impact of landholding size in economic development of a region and then finds out what is the level of landholding size among Scheduled Caste population in Azamgarh to estimate their level of socio-economic development. Apart from this, the chapter also analyses the regional disparities in the distribution of landholding size between the different community development blocks of Azamgarh district.

\section{Landholding Size vis-a-vis Economic Development:}

Even though major cities in developing countries are characterised by urban poor and slum populations, global poverty is still overwhelmingly a problem of lower agricultural income in less developed countries(World Bank 2016). This is despite the fact that many new developments in agricultural technology have made farming more rewarding, but this is largely limited by the small farm sizes. For example, Adamopoulos and Restuccia (2014) show that greater than $70 \%$ of the agricultural land in developing countries is less than 2 ha. 
Because of small farm size, farmers in developing countries are often badly affected by vagaries of weather or because of shocks through financial and agricultural systems, which can quickly turn to conflict (Couttenier and Soubeyran 2014, von Uexkull et al 2016, Crost et al 2018, Harari and La Ferrara 2018). On the other hand, large farms work under totally different economic model of commercial production and is therefore, not as dependent on such shocks (Rosenzweig and Binswanger 1993). For example, they may leverage their larger farms to diversify their risks by planting more or different crops.

Because of the above mentioned importance of landholding size to economic and social development, the current study tries to find out the level of landholding size among Scheduled Caste farmers in different blocks of Azamgarh district of Uttar Pradesh.

\section{Database and Methodology:}

To find out the landholding size of Scheduled Caste population in Azamgarh, a primary survey of 427 persons was conducted in Azamgarh. The survey was spread over all the 22 community development blocks of Azamgarh. The respondents were $12 \%$ female and $88 \%$ males, while according to age group, $29 \%$ were above the age of 46 , $43 \%$ were between the ages of 30 to 45 , and $27 \%$ were below the age of 30 . The age and gender differentials of respondents are given in graph below:

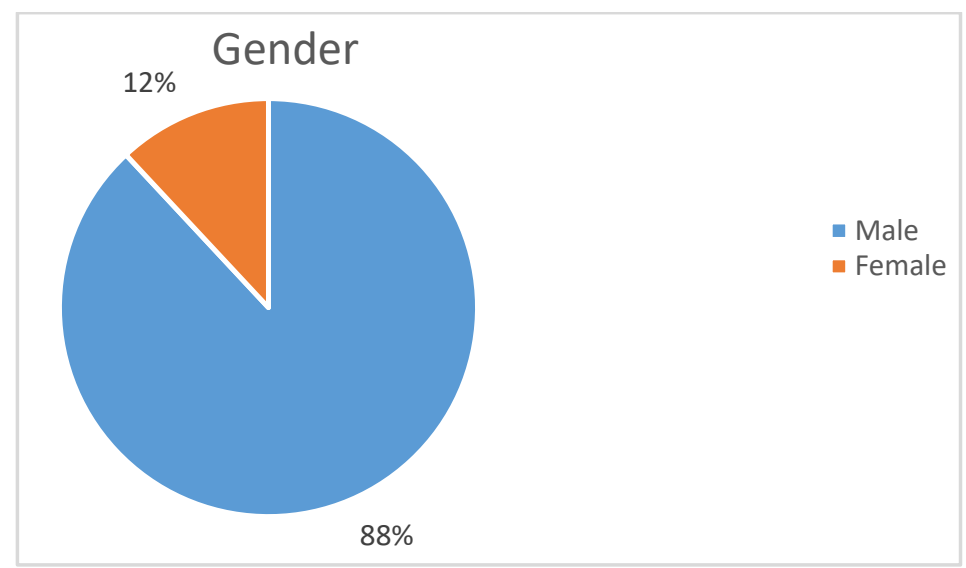

Figure1: Gender of primary survey respondents

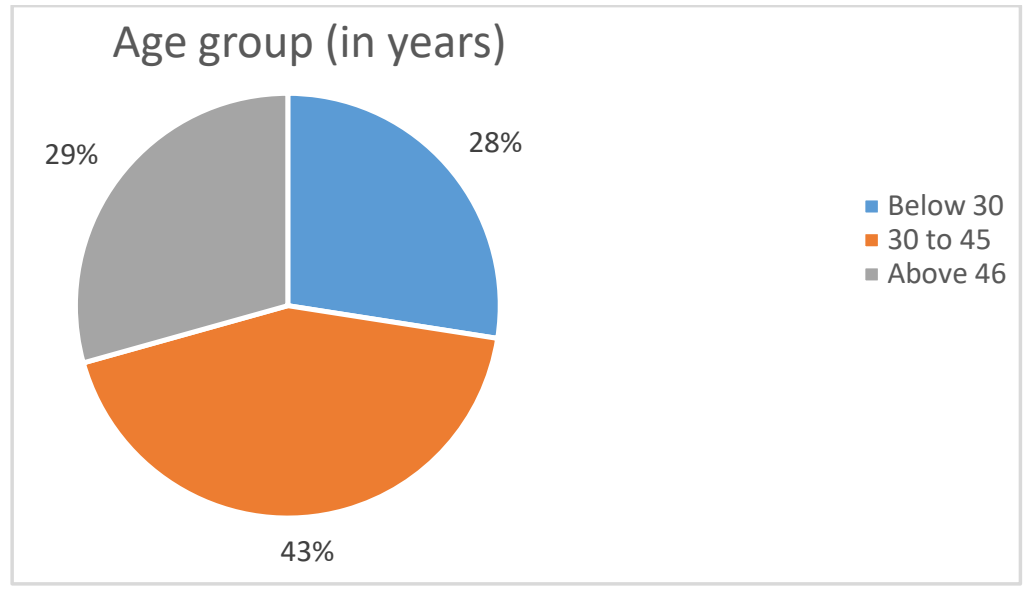

Figure 2: Age group of primary survey respondents

\section{Results and Discussions:}

According to the survey, it was found that a majority of Scheduled Caste population (68\%) own less than 1 hectare (ha) of land. Moreover, only about $4 \%$ of the population own 4 ha or above (the highest category). This is shown with the help of graph as given below: 


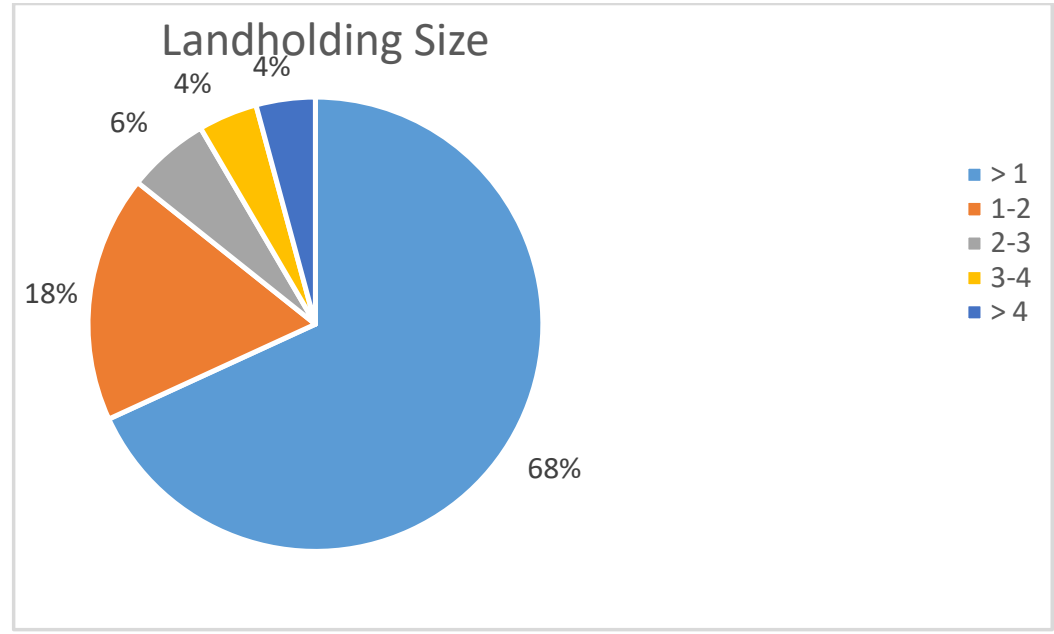

Figure 3: Landholding Size

Source: From Primary Survey

Apart from this, there exists a regional disparity in distribution of land in Azamgarh district. Only 4 community development (CD) blocks have 2 persons (out of total surveyed population) who own 4 ha of land or more. This is in contrast to $8 \mathrm{CD}$ blocks that have 0 persons (out of total surveyed population) who own 4 ha of land or more. Moreover, an overwhelming majority of all CD blocks have more than 10 persons (out of total surveyed population) who own less than 1 ha of land. This is given as a table and represented in map given below:

Table 1: Landholding Size

\begin{tabular}{|c|c|c|c|c|c|}
\hline CD Blocks & $0-1$ & $1-2$ & $2-3$ & $3-4$ & $>4$ \\
\hline Atraulia & 13 & 2 & 0 & 1 & 2 \\
\hline Koilsa & 13 & 6 & 4 & 1 & 0 \\
\hline Ahiraula & 21 & 1 & 4 & 1 & 0 \\
\hline Mahrajganj & 15 & 3 & 1 & 0 & 0 \\
\hline Haraiya & 15 & 4 & 0 & 0 & 2 \\
\hline Bilariyaganj & 19 & 2 & 1 & 0 & 0 \\
\hline Azmatgarh & 12 & 3 & 0 & 0 & 0 \\
\hline Palhani & 13 & 5 & 2 & 2 & 2 \\
\hline Rani Ki Sarai & 14 & 3 & 1 & 2 & 3 \\
\hline Sathiyaon & 18 & 2 & 0 & 1 & 1 \\
\hline Jahanaganj & 9 & 1 & 3 & 1 & 0 \\
\hline Tahbarpur & 13 & 1 & 0 & 2 & 1 \\
\hline Mirzapur & 10 & 2 & 0 & 2 & 0 \\
\hline Mohammadpur & 9 & 4 & 0 & 0 & 2 \\
\hline Pawai & 12 & 5 & 1 & 0 & 1 \\
\hline Phulpur & 12 & 2 & 3 & 1 & 0 \\
\hline Martinganj & 11 & 4 & 1 & 0 & 0 \\
\hline
\end{tabular}




\begin{tabular}{|c|c|c|c|c|c|}
\hline Thekma & 11 & 9 & 1 & 1 & 0 \\
\hline Lalganj & 17 & 2 & 2 & 1 & 0 \\
\hline Tarwa & 15 & 5 & 0 & 1 & 1 \\
\hline Mehnagar & 9 & 4 & 1 & 0 & 1 \\
\hline Palhna & 10 & 5 & 0 & 1 & 2 \\
\hline Total & 291 & 75 & 25 & 18 & 18 \\
\hline
\end{tabular}

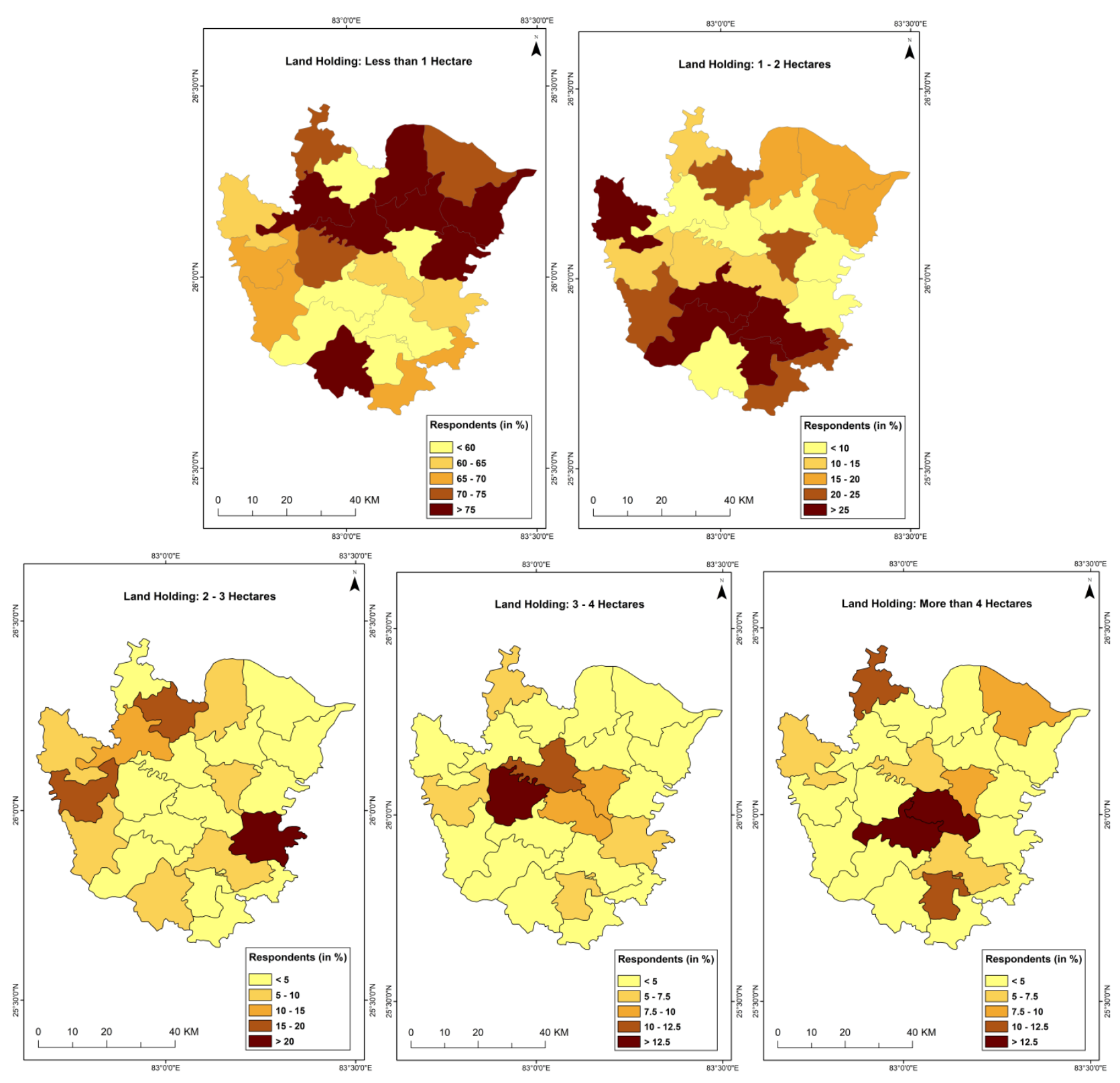

Source: Primary Survey

Map 1: CD block wise land distribution among SC population in Azamgarh district: a) Less than 1ha; b) 1-2 ha; c) 2-3 ha; d) 3-4 ha; e) greater than 4 ha.

\section{Conclusion:}

From the discussion on impact of landholding size on economic development and the data on landholding size among Scheduled Caste population, it is clear that the SC population in Azamgarh district is highly deprived. The overwhelming majority of SC farmers in Azamgarh own only a tiny fraction of land (less tha $1 \mathrm{ha}$ ), and a very 
small proportion own 4 ha or above. Thus, to better develop the Scheduled Caste population in Azamgarh economically, it is necessary to better distribute land among the farmers here.

\section{References:}

Adamopoulos T and Restuccia D (2014) The size distribution of farms and international productivity differences Am. Econ. Rev. 104 1667-97

Blattman C, Fiala N and Martinez S (2013) Generating skilled selfemployment in developing countries: experimental evidence from Uganda Q. J. Econ. 129 697-752

Bryan G, Chowdhury S and Mobarak A M (2014) Underinvestment in a profitable technology: the case of seasonal migration in Bangladesh Econometrica 82 1671-748

Couttenier M and Soubeyran R (2014) Drought and civil war in SubSaharan Africa Econ. J. 124 201-44

Crost B, Duquennois C, Felter J H and Rees D I (2018) Climate change, agricultural production and civil conflict: evidence from the Philippines J. Environ. Econ. Manage. 88 379-95

Harari M and La Ferrara E (2018) Conflict, climate, and cells: a disaggregated analysis Rev. Econ. Stat. 100 594-608

Jensen R (2012) Do labor market opportunities affect young women's work and family decisions? Experimental evidence from India Q. J. Econ. 127 753-92

Rosenzweig M R and Binswanger H P (1993) Wealth, weather risk and the composition and profitability of agricultural investments Econ. J. 103 56-78

von Uexkull N, Croicu M, Fjelde H and Buhaug H (2016) Civil conflict sensitivity to growing-season drought Proc. Natl Acad. Sci. USA 113 12391-6

World Bank (2016) Poverty and Shared Prosperity 2016: Taking on Inequality (Washington, DC: World Bank) 